\title{
Governor Sir John Field in St Helena: Democratic Reform in a Small British Colony, 1962-68
}

In the age of decolonisation, Whitehall generally accepted the case for political advancement even in small British colonies like St Helena judged too lacking in resources to become independent states, provided this could be granted without risk to good government. The previous experience of Sir John Field in West Africa and his sensitivity to UN expectations lay behind the democratic reforms he introduced, which by 1968 had established an elected Legislative Council and an Executive Council made up mainly of LegCo members. But the steps he took owed little to sustained popular demand for self-government, as was common elsewhere, and much to his determination to make islanders politically more responsible. Public engagement was inhibited by practical constraints, local culture, and a discouraging financial dependence on the UK government.

On 13 May 1962, Sir John Field boarded the launch which took him and Lady Field from the Union-Castle liner anchored in the bay to the wharf at Jamestown to take up his post as governor of St Helena in the South Atlantic. ${ }^{1}$ Since access to the island was only by ship and the scheduled passenger service took over two weeks to travel the 4500 miles from the UK, he would have had ample time to reflect on his responsibilities and the task ahead. He had been made responsible for the well-being and good government of around 4600 people of mixed Asian, African, Chinese and European origin, living on an isolated island of just 47 square miles. ${ }^{2}$ Six years later, on 25 May 1968, his term of office completed, Sir John and Lady Field boarded the Good Hope Castle, bound for Cape Town, for a period of leave before returning to London. This was a shorter journey, just four days, but enough for reflections on what he had achieved. 'I hope I have done some good', he wrote in his journal, 'and I venture to hope that I have been a successful Governor.' Many on the island thought so, and also ministers in London. Not only had he been awarded a KBE in 1967, but in 1970 when senior posts in the diminishing Colonial Empire were becoming rare he became Resident Commissioner, later Governor, of the Gilbert and Ellice Islands.

His achievements included the transformation of St Helena's constitution. Field inherited a system of government strongly resembling conventional crown colony administration: a governor working with an Executive Council responsible for policy-making and administration made up of four expatriate officials, to which had been added, but only in 1956, three non-officials. These three were selected by the governor from an Advisory Council of up to ten members, all appointed by the governor, two of whom were to represent the island's friendly societies and five the district associations which had been formed recently in the small settlements around the island. ${ }^{3}$ The Advisory Council so composed was supposed to enable the governor to tap into local opinion, but as its title indicates it had no legislative or administrative functions, and it met in private. By the time Field left, it had been transformed into a law-making Legislative Council, meeting in public under the presidency of the governor, made up of twelve councillors to be elected in secret ballots by registered adult voters in ten constituencies. Only the government secretary and the colonial treasurer also attended. Those elected also became members of six LegCo committees responsible for managing important areas of government administration: agriculture and natural resources, public works and services, social welfare, public health, and education, plus finance to which the chairs of all the other committees automatically belonged. Except for finance, headed by the colonial treasurer, committee chairs were to be elected LegCo 
members, albeit chosen by the governor. They also became members of a transformed Executive Council, presided over by the governor, which otherwise included only the government secretary and the colonial treasurer. ${ }^{4}$

This was indeed a radical constitutional change, but on the face of it only following, belatedly and partially, the early steps towards democratic accountability which post-war had already seen the ending of imperial control in south Asia in the late 1940s, over the larger African colonies from the late 1950s, and subsequently elsewhere. In explaining the timing of British decolonisation, emphasis is usually placed on the pressure from popular nationalist movements, as well as - varying erratically over time and from place to place - the inability or often the unwillingness of the British government to resist most demands for political change and even independence, for financial, economic and political reasons, including a sensitivity to American and increasingly United Nations opinion. In February 1946 the UN General Assembly had instructed colonial powers to report on economic, social and educational conditions in their colonies, and additional demands for political change and decolonisation culminated in Resolution 1514 (XV) in December 1960, setting out the acceptable options leading to self-determined independence for colonial peoples. Equally important was the establishment in 1961, shortly before Sir John Field took office in St Helena, of what came to be called the UN's Committee of Twenty-Four, which monitored progress and insisted on more rapid change. ${ }^{5}$

However, while UN pressures may, at best, have hurried along the ending of formal empire in the larger colonies, ministers and officials in London also had to address the question of how far and in what direction political change could be allowed or even encouraged in what were initially loosely described as the 'Smaller Colonial Territories' and when their numbers diminished the 'Remaining British Dependent Territories'. Whether all independent former colonies, irrespective of size, should be accorded equal status if they opted to join the Commonwealth was one matter that troubled its initial founder members including the UK government, ${ }^{6}$ but the latter also fretted that several small colonies seemed to lack the size, population, natural resources and viable economy they would need in order to function as independent states. Nevertheless, even in what were expected to remain dependent territories, colonial constitutions might still need amending to increase local involvement in colonial government. But how much demand was there locally for more public participation in the government of small colonies, and would an adequate response be more, or more democratic, representation on advisory councils or perhaps on executive councils? Could even internal self-government be allowed for colonies which were - and likely to remain - financially dependent on UK aid or were of strategic importance? Was something like a Westminsterstyle government really suitable for small communities, or would something akin to a municipal authority with specific but limited responsibilities be more suitable? Were best options merger or federation with other small or adjacent territories, or a Channel Islands or Isle of Man relationship with the UK, or even integration with the UK and parliamentary representation in London (seriously considered for a while as an option for Malta and Gibraltar)? Would any partial changes be acceptable to the Committee of Twenty-Four, which certainly did not (yet) regard the future of small colonies as marginal to its mission? Possibilities and what might be the ultimate political destiny of such territories were therefore the subject of a sequence of official explorations, beginning in 1949 with the Committee of Enquiry into Constitutional Development in the Smaller Colonial Territories, with several more to follow through the 1950s and 1960s. They had little practical outcome, being overtaken by events, but the many papers they generated repeatedly acknowledged the need for constitutional changes in small colonies, some time, somehow. ${ }^{7}$ 
St Helena always figured among the 'smaller colonial territories' which were never thought likely to become independent, ${ }^{8}$ and indeed it remains today a lingering legacy of empire, one of the dozen or so British Overseas Territories. ${ }^{9}$ Of course, the way in which St Helena was governed had changed since the Crown had taken over responsibility in 1834 after 175 years of East India Company rule. Nevertheless, even by 1962 when Field took charge, the constitution had not departed far from autocracy. There had been sporadic local demands for elected representation on the governor's councils, led by the few major landowners and members of the Chamber of Commerce, particularly when protesting against the taxes needed to help finance government services. For this reason, such demands tended to be treated by officials as selfish sectional concerns. ${ }^{10}$ Indeed, it was repeatedly stated by governors and accepted by Colonial Office staff that Saints (as the island-born are now commonly called) were in general uninterested in constitutional change. Governor George Joy in 1949 agreed with the assessment of his two immediate predecessors that 'the people' did not wish to become involved in island administration. 'Elsewhere the problem is that of yielding successive powers to a populace vociferating for self-government. Here, the problem is that of encouraging a diffident people to demand and accept responsibility for their internal affairs'. His monthly tea parties with the (unelected) members of his Advisory Council were, he reckoned, a quite sufficient innovation. ${ }^{11}$

To be fair, Joy was concerned about this apparent apathy, and certainly Governor James Harford, his successor in 1954, identified this as a problem to be addressed. In the context of the Colonial Office's wider deliberations on the need for constitutional development in the 'smaller colonial territories', suggestions for change in order to encourage islanders to become more involved in the island's administration were then batted between Harford and the Colonial Office for a couple of years until in March 1956 new constitutional instruments were issued. Membership of the Advisory Council was to be increased, and those appointed (not elected) were supposed to be more representative of island communities and to arouse local interest, but the only substantial change was the selection by the governor of three members of this larger Advisory Council to sit also on his Executive Council - and this it seems because by then an Executive Council made up entirely of officials was thought to be unique in Britain's colonial empire. Harford had consulted only current members of his Executive and Advisory Councils and of the Chamber of Commerce, and had confidently concluded that there was as yet no significant demand for democratic elections. ${ }^{12}$ Indeed, prior to him leaving office in January 1958, there were few signs of that wider political interest which constitutional modifications had been intended to encourage. But then, suddenly, everything seemed to change.

\section{II}

Early in 1958 an expatriate settler contacted the British Labour Party to complain about conditions on St Helena and its form of government. In response and at the request of the party leadership, Cledwyn Hughes, MP for Anglesey, visited the island in June-July 1958. His report was highly critical of what he found, including the island's undemocratic constitution. He proposed an Advisory Council of fifteen members, elected by adult suffrage, who should also elect six of their number to serve on the Executive Council alongside only two officials. ${ }^{13}$ The mainstays of the local economy had been the shipping which in huge numbers had once called at the island for supplies, but not since the later $19^{\text {th }}$ century; plus the demand generated by a resident garrison, which had been withdrawn early in the 20th century. Now it was largely dependent on a low-wage flax-growing and fibre-making 
industry, already in terminal decline. Much of the island's infrastructure, housing and public services therefore depended on recurrent budgetary aid and whatever development money the UK government provided. Islanders had reason to complain, and at a public meeting prior to his departure Hughes was asked to advise on setting up a trade union.

The St Helena General Workers Union [GWU] was formed immediately, in July 1958. Fred Ward, then aged 42, became its charismatic, energetic and, to be frank, intemperate general secretary. Like many Saints he was of mixed race origins, but his aspirations for islanders had been unusually sharpened off-island by wartime service in the South African military, travel worldwide in the merchant navy, and employment in South African goldmines. He returned to St Helena in 1953, opened a shop with his wife, and began to use the (government-edited) press to attack what he saw as government maladministration. ${ }^{14}$ The GWU public meetings he now addressed, the protest marches he headed, and the strikes (and New Year's Eve dances) he organised attracted such support that by July 1959 the union claimed a membership of 2025, or 'most of the entire employed population', including not just men and women employed in the flax industry, but wharf workers, general labourers, low grade government employees, and even, it was said, housewives. ${ }^{15}$ Here at last was the voice of the people, or at least The Voice of the Union as its highly polemical and occasionally libellous campaigning newsletter, entirely written by Ward, was called. His complaints about the colonial government were addressed to the Colonial Office, TUC, ICFTU and of course Hughes. Crucially, Ward insisted that democratic representation was essential if living standards were to be raised. He demanded at the very least a wholly elected Advisory Council. ${ }^{16}$

In the context of political demands elsewhere this was not extreme nor might its origins seem remarkable. By 1958, trade unions were widespread in British colonial territories, and agitation over terms and conditions of labour and demands for social improvements were often coupled with pressure for political reform and sometimes linked to nationalist movements. ${ }^{17}$ But what had developed in large colonies in Africa and in such territorially small but densely populated colonies as Singapore, Hong Kong, Aden, Gibraltar and in the West Indies seemed astonishing when tiny and seemingly docile St Helena erupted. True, the Colonial Office, primed by Robert Alford, the new governor who had arrived in February 1958, was aware that Saints were not so saintly as to be insensitive to low pay, poor housing and rising unemployment, ${ }^{18}$ but organised discontent was such a shock that a senior official from the Colonial Office (Aaron Emanuel, an LSE-trained economist) was dispatched in March 1959 on an almost unprecedented visit to the island. He was struck by the strength of feeling, the legitimacy of local concerns and the risk of public disorder. In agitated telegrams and in his subsequent report he recommended immediate relief measures, action to address economic decline, investment in public services and further constitutional change as necessary responses to what seemed serious problems. ${ }^{19}$

The pressure on Governor Alford from the GWU was such that in July 1959, after a year of agitation, he too albeit reluctantly was ready to accept, with the inclusion of two ex officio members, an otherwise wholly elected Advisory Council. But opinion was divided in the Colonial Office, where the constitutions of other small colonies were examined and compared, and Alford also changed his mind, but it was only opposition from almost all the unofficial members of the current Executive and Advisory Councils (largely the island's few well-to-do employers) which instead caused the secretary of state in July 1960 after a further year of deliberation to insist that only half the sixteen members of an enlarged Advisory Council should be elected while four non-officials (and four officials) should still be 
nominated by the governor, supposedly to give voice to 'minority opinion'. Moreover, pending the drafting of a new constitution, another Advisory Council as currently composed was appointed, possibly for a further three years while the new system was put in place. This limited concession and its delayed implementation were denounced by Ward, still insisting, at once, on an entirely elected Advisory Council. Attempts by Alford to rally local opinion behind the official proposals also failed to catch fire, and with relations between union and governor so bitter during 1961 no settlement had been reached and no election held (partly because the Colonial Office feared a boycott) before his term of office was concluded. ${ }^{20}$ On 2 March 1962 Alford left the island.

In drawing up what were in effect a 'job description' and a 'person specification' for his successor, it was now recognised in the Colonial Office that someone special was needed to fill the post since 'St Helena is no longer an easy and restful place, and there is considerable discontent to a large extent but not wholly stirred up by one or two local "agitators" who may prove troublesome'. ${ }^{21}$ John Field's Colonial Service career went back to 1936 and his appointment, aged 23, as a cadet administrative officer in Nigeria, by when political challenges were already altering the politics of the Colonial Empire. His sensitivity to risks and needs was sharpened by his subsequent service as senior assistant secretary responsible for security and defence matters in the colony's secretariat in Lagos from the late 1940s to 1953, during which period a largely unitary constitution was devised and launched in 1947 but revised in 1951. Then, appointed in 1953 as a senior district officer and later resident in Nigeria's Eastern Region, he was confronted by regional objections to a centralised state. Recalled to Lagos as principal assistant secretary and then deputy chief secretary, he became involved instead in drafting and launching Nigeria's 1954 federal constitution, after which as UK commissioner (in effect governor) for the UN Trust Territory of Southern Cameroons from 1956 he was engaged in the local and London conferences which culminated in Nigerian independence in 1960. In these senior roles Field worked with African elected ministers and officials. Also, as commissioner and therefore frequently in New York as a special UK representative on the UN's Trusteeship Council, he was made still more acutely aware of which way the political wind was blowing. Since in 1961 he had conducted a plebiscite in the Southern Cameroons to determine its future by popular vote (to become part of Nigeria or join the Federal Republic of Cameroon), he also knew a thing or two about ballot boxes. Indeed, Field's handling of constitutional matters counted much in his favour, and he was judged pretty unanimously by senior Colonial Office staff as the most suitable out of the half dozen candidates considered for the post. Field himself acknowledged the value of his experiences in West Africa for his programme for change on St Helena, for 'there was practically no form of constitutional development or civic machinery that we did not have to cope with'. And so, having been responsible in Africa for the well-being and political future of very large populations across huge spaces, for which he acquired his knighthood, Sir John was now to govern a few thousand people on an island in the south Atlantic apparently in a state of unrest. ${ }^{22}$

Field had been briefed at the Colonial Office before he set off, and also by the TUC and in a meeting with Cledwyn Hughes, so he had a pretty shrewd idea about the situation he would find. ${ }^{23}$ But his immediate task had been made easier because Ward had at last agreed to compromise on the constitutional reforms which had so long been stalled. ${ }^{24}$ Since the dispute between GWU and governor had become a highly personalised confrontation (as issues of the Voice of the Union only too sharply reveal and as Alford recognised), ${ }^{25}$ it was the departure of Governor Alford which at last allowed Ward to accept the advice which Cledwyn Hughes had repeatedly pressed upon him - personally when Ward late in 1959 had been in London 
attending a trade union training course (paid for by the TUC) and thereafter in letters over the following years which Hughes had despatched to St Helena. George Woodcock, General Secretary of the TUC, had similarly urged Ward to think carefully about his stubborn opposition to the constitutional changes on offer lest it damage the union's other campaigns. $^{26}$ There were also signs during 1961 that popular interest in constitutional reform was on the ebb, a sign of things to come, and such a shift may also have persuaded Ward to secure what was on offer. ${ }^{27}$ The governor would still appoint half the members of the Advisory Council - four officials and four non-officials - but the other eight were to be democratically elected, one from each of eight constituencies. In addition, while all seven members of the Executive Council were still to be appointed by the governor, they were to include three of the non-officials serving on the Advisory Council, and, as a concession to the GWU, one of them had to be an elected member - a proposal which Field himself had volunteered at his briefing in the Colonial Office. ${ }^{28}$ Grass roots pressure had had some effect. It was now for Field to introduce these changes.

Over the next six years, he was to be responsible for many more. Considering what was happening elsewhere in the colonial world, one might expect Governor Field to be driven further forward by the heated demands of a politicised public, led by a GWU ratcheting up its requirements. In fact, much of the subsequent democratisation of St Helena was top down, engineered by a governor convinced by experience that the local population needed to be taught democratic practice and educated in democratic responsibilities. Field had concluded from his dealings with the UN that unless constitutional changes were made, and soon, the UN's Committee of Twenty-Four would 'start sticking their oar in and making a nuisance of themselves'. This, more politely expressed, was the motive for change he set down for the Colonial Office in December 1962 in response to an enquiry about political futures addressed to the governors of all the 'smaller colonial territories'. St Helena, in free association with the UK, should become as much as possible internally self-governing, with a Legislative Council elected by adult suffrage; the governor would retain reserved powers but otherwise should be bound to act on the advice of an Executive Council composed mainly of members of the Legislative Council elected by their colleagues. Here indeed was ambition, laid down early, and ahead of the game. But, he concluded, 'The speed at which these changes could be introduced would depend on how long it took to overcome the apathy of the people but the aim should be to complete the process within five years'. ${ }^{29}$

III

The immediate need was to establish and operate St Helena's partially-elected Advisory Council. Only a few expat settlers and officials, and maybe some Saints who had lived abroad, would have had experience of a general election. During his period as governor, Field organised two, plus four by-elections, and always he found it hard work to generate public involvement. His efforts included using the government-run newspapers, the weekly St Helena News Review and the monthly St Helena Wirebird, to inform, instruct and enthuse. Prior to St Helena's first election in September 1963, he explained how elections were conducted, how to register as voters, how to get nominated as candidates, and why all this mattered. This may seem elementary stuff, but as he wrote, with reasonable accuracy, it was necessary 'since nobody has any idea what the election is all about and seem to think it can all be done by a show of hands at some sort of public meeting'. He also addressed wellpublicised meetings around the island to explain and encourage, even showing films of polling days elsewhere by way of illustration. ${ }^{30}$ 
The registration of voters would be the first test of whether these efforts to generate political involvement had been effective. Voters had to be British subjects, aged 21 or over, and ordinarily resident in St Helena for at least a year before registration. Registration forms were made available from offices and shops throughout the island and in copies of the News Review, which like the Wirebird also urged readers, repeatedly, to register. The response was underwhelming. After two weeks only 330 people had registered, after a month just over 800 , out of a potential electorate of 2000 or so. Not satisfied with the number netted, Field extended the registration period, but the final figure of 969 at the end of July 1963 was 'still small compared with the number of people on the island eligible for registration', ${ }^{31}$ and indeed less than half of the reported membership of the GWU in 1959.

Persuading candidates to stand generated additional challenges. Field knew whom he wanted on the new Advisory Council. He was aware that the four official members to be appointed would be from overseas, and probably one of the four non-officials he was required to nominate. Those five among sixteen councillors were, he reckoned, a 'large enough proportion'. By implication, the others and certainly the eight to be elected should be local folk: 'My job was to try to make St Helenians take an interest in public affairs and speak for themselves'. With such political instincts in mind, he used the government press to stress the importance to islanders of the Advisory Council's business and to urge candidates, including women, to come forward. Perhaps as a result, and contrary to Field's fears, there were nineteen nominations, including three women. However, there would be elections in only six of the eight constituencies since only one candidate had been persuaded to stand in each of the other two. He concluded, somewhat ruefully, that on the whole 'the candidates are not a bad lot and it is encouraging that so many people are prepared to stand after all'. But he was irritated that the bishop of St Helena, British-born and a former Royal Navy chaplain, had declared his intention to stand for election and could not be dissuaded.

Registered voters still had to turn out and vote. Field had micro-managed the preparations, ensuring that constituency boundaries had been defined and publicised, voting papers had been printed, ballot boxes constructed, polling stations prepared and election officers rehearsed in their duties, and the electorate had been reassured that their votes would remain secret. 'Everything is now in your hands ... and it simply remains for YOU to complete the last stage of St Helena's first elections by going to the poll and casting your vote. Having done this you can truthfully say that you have done your part to help ST HELENA along the path of political development. ${ }^{32}$ He was anxious, but in fact the overall turn-out in contested seats was good, though, given the modest number of people who had registered, the votes cast in each contested constituency were still few, ranging from 64 to 192 . Obviously, he wished that more islanders had registered and then voted and that all seats had been contested, but it was still 'a real historic day for St Helena' because it was 'the first occasion in the long history of the island that elections were held to give the people an opportunity to elect eight candidates to the new Advisory Council', albeit to sit alongside eight others he would nominate. ${ }^{33}$

Moreover, and this pleased him, all but one of those elected were St Helenians. Two were employees of Cable and Wireless Ltd, two were housewives, and the others a foreman in a flax mill, a small farmer, and a self-employed carpenter and boat builder. Only a couple of candidates, one of whom was elected, had explicit GWU associations, but this was an election contested not by organised parties but by individuals, voted for by neighbours, perhaps based primarily on personality and current public standing. But the election of the bishop scuppered Field's plan to invite the eight elected members themselves to choose the 
one elected member of the Advisory Council who would also sit on the Executive Council. Field was certain that the bishop would see to it that his seven colleagues would propose himself, and because Field was determined to keep him off the Executive Council he was forced to restrain his democratic instincts, stick to an old regime practice of the governor making the selection, and thereby secure another authentic St Helenian on that council, a selfemployed farmer who 'therefore should [be] independent', a man 'with ideas of his own, which is what we want'. A constitution combining popular democracy with his continuing right to exercise gubernatorial authority ensured that eleven of the sixteen members of the new Advisory Council were Saints, as were the three non-official representatives of that council on his Executive Council.

The old Advisory Council had met with the governor in private in the Castle, the administrative seat of government, but this was incompatible with Field's democratic principles, so it was not merely for convenience that meetings of the new and enlarged Advisory Council were held in public in the Supreme Court building. Its location in Jamestown's main square was more likely, he judged, to persuade people to drop in and see democratic debate in action, and he used the News Review to publicise council meetings and encourage attendance, and subsequently to report on matters discussed at council meetings. In his opening address to the first meeting on 16 October 1963, he also pressed the democratic button by stressing that elected councillors were 'accountable, not to the Governor or to themselves, but to the people who elected them'. Meetings were therefore open 'as it was the right of the public to know how the Council was dealing with their affairs'. It would have pleased him to see about fifty attending that inaugural event. ${ }^{34}$

However, while several overseas people came to listen at a subsequent Advisory Council meeting in June 1965, only one St Helenian was present. Because council sessions had been held in the morning when, perhaps, 'the younger and more alert St Helenians were at work', he arranged for the next meeting to be in the evening 'in the hope that it would provide a better opportunity for more people to listen'. But evenings are dark all the year round in St Helena and the Supreme Court building lacked adequate lights, 'and there may not be any spare money to get them put in'. Getting St Helena's democracy to shine more brightly encountered peculiar difficulties. However, the lights must have been fixed, because so many turned up to the evening meeting in September 1965 that all the seats were taken and the overflow had to stand at the door. But Field suspected it was only the proposal under discussion to allow government tenants to buy their houses that had attracted so many. He was right to be sceptical. When council next met, to consider the annual budget, town and country planning legislation, and making women eligible for jury service, only a dozen people came to listen. ${ }^{35}$ Once the novelty had worn off, public interest largely evaporated.

If council meetings were to retain an audience and be constructive, councillors needed to engage in democratic debate in public. At the inaugural meeting Field had stressed that the role of councillors was to advise the governor on all internal matters upon which he sought advice, including draft legislation, but also that constructive criticism of government was 'salutary and a perfectly good and legitimate way of tendering advice'. Moreover, council did not have to speak with one voice, and councillors should also bring up other issues as they saw fit. ${ }^{36}$ His aim from the beginning was clear. He intended 'to run the Council on parliamentary lines with a view to turning it as soon as possible into a proper legislative council'. That meant following agreed rules of procedure, for which he adopted those he had drawn up for the advisory council of chiefs in Southern Cameroons. He acknowledged in his journal after that first meeting that several councillors had contributed to discussions on one 
item of business, a road traffic ordinance, but after meetings in November 1963 he could only record that he was 'not too dissatisfied since members are still feeling their way'. In May 1964, one councillor proposed a private member's bill and others put down questions, like backbench MPs at Westminster, which he as governor after consulting departmental heads was obliged to answer, but there was little debate and business was dispatched in an hour. Even after a better meeting in November 1964, Field still felt that councillors 'have very far to go before they even begin to be a little parliament'. Councillors too were conscious of their inexperience, so at their request he staged mock debates and instructed them in how to deal with an amendment to a resolution, the procedure to follow when a division was called, and how to bring up supplementary questions in response to an official answer to a tabled question. He conceded that councillors learnt from the exercises, but they still 'did not debate very well'. He had nagging doubts as to whether they would ever be able to operate any sort of parliamentary system. What mattered was that 'they should discuss public affairs publicly and have the courage to come out into the open with their views, and that is what they are most reluctant to do'. This was a continuing problem. The Advisory Council meeting in June 1965 was 'very depressing'. There were eight draft bills to consider, but 'nobody spoke a word' and the entire business was disposed of in two hours, leaving Field to wonder 'whether there is any prospect of ever getting a legislature going here.'

\section{IV}

The reformed Advisory Council had not been a success. Elected members may have done useful work, looking after the interests of their constituents by raising issues with the heads of government departments, as Field had urged, but public involvement in elections had been limited, attendance at council meetings was patchy, and the quality of debates generally poor. Perhaps this was partly because meetings of the Advisory Council were irregular and infrequent, only four times from October 1963 to June 1965, whereas the Executive Council met at least eight times in 1964 and ten times in $1965 .{ }^{37}$ But the real problem, as Field saw it, was that the Advisory Council had few responsibilities because it was not intimately involved in the regular administration of the colony. While he discerned no demand locally for further constitutional reform, he still believed that change was needed if criticism from the UN were to be avoided. After developing his ideas in his journal, in September 1965 he put proposals to the Colonial Office which, he hoped, would more effectively advance democratic selfgovernment.

He had to hand a model of his own invention. At the inaugural meeting of the Advisory Council in 1963, he had mentioned that some business might be dealt with by ad hoc committees made up of councillors plus others with requisite technical expertise. A development committee and a housing committee had indeed been formed to examine schemes and recommend priorities for funding. ${ }^{38}$ Field now contemplated setting up similarly composed standing committees and charging them with responsibility for 'the general oversight and supervision of departmental activities'. They might also take over the duties of several statutory bodies which scarcely functioned because, individually, they had so little to do. The committees would not be involved in the detailed running of departments and would not be responsible for staffing matters, but such a system would give councillors 'something specific to do' since a great deal of administrative business would be their concern. He also wanted the Advisory Council to be retitled the Legislative Council in recognition of councillors' responsibilities and to enhance its status. All he asked was that he should be authorised to carry out informal consultations, which the Colonial Office, after 
rattling around among precedents and dwelling on possible implications and without commitment, was pleased to grant. ${ }^{39}$

The surprisingly enthusiastic responses Field then received from those whose views he respected emboldened him to press ahead with further recommendations that he had originally thought might only be rolled out later. First, chairs of the Legislative Council committees should at once be brought into the administrative heart of colonial government by making them members of the Executive Council, and, second, after the life of the current Advisory and soon to become Legislative Council expired in October 1967 and before the next general election, two of its four nominated official members should be removed and all four of its nominated unofficial members replaced by four more elected councillors, to create a LegCo made up of twelve elected and just two ex officio members. ${ }^{40}$

In May 1966, the Colonial Office gave its initial blessing, then finally and formally in September; and while officials set about drafting new statutory instruments, ${ }^{41}$ Field selected members of the current Advisory Council to chair his new Legislative Council committees (and thereby become members of his new Executive Council). But the appointment of other committee members, including people with technical knowledge who were not councillors, he devolved on to a selection committee of two council members who were islanders, plus the government secretary. Field was determined to devolve responsibilities, even this one, on to St Helenians. He also explained to the heads of government departments how, under the new constitution, they needed to work closely with the new committees and especially to keep their chairs fully informed of what was 'going on'. With appointments made, teams briefed, standing orders drawn up and with perhaps a sigh of relief, Field wrote that 'it should now be possible to bring the new Constitution into force on $1^{\text {st }}$ January, 1967'. It was.

But it was still a worry that in June 1966 he had secured the formal agreement of the Advisory Council to his constitutional innovations not only 'without a hitch' but indeed on this and other matters with practically no debate, 'as usual'. Moreover, at two by-elections in September 1966 and in spite of much urging in the press, only one candidate came forward in one constituency, and while two stood at the other only 39 votes were cast (84 in 1963), hardly indicating 'any particular enthusiasm for the parliamentary system or democratic processes'. Nor was he pleased in October 1966 when 'practically nothing was said' at the next and indeed final meeting of his Advisory Council. He could only hope that his constitutional reforms would gee things up, 'otherwise there is a poor look out for any sort of constitutional advance in St Helena'. After the formal opening on 17 January 1967 of the first Legislative Council, he was better pleased by a brisk debate on the draft budget, and he recorded later that the LegCo committees had 'got off to a gratifyingly good start' and were 'tending to probe into government policies and activities and by no means take everything officials tell them on trust. That is as it should be'. ${ }^{42}$ But in September 1967, at a council byelection and after much urging in the government press, there was only one candidate, returned unopposed, and he was not a Saint but an expat. It filled Field with foreboding: 'I hope some good may yet come out of it by bringing home to the people', by which term he always meant true St Helenians, 'that if they don't take the trouble to field candidates of their own, they stand the risk of having their affairs run for them by overseas people.' He felt the constitution he had designed was sound, 'but there is still the risk that the whole lot will fall down because not enough people will stand for election. I shall be sadly disappointed if that happens'. 
He was to be disappointed. St Helena's first general election in 1963 had been to elect eight candidates to make up half (only) of an Advisory Council (only). The general election scheduled for February 1968 was to elect twelve members of a Legislative Council who would also serve on committees supervising government business, including those who as committee chairs would become members of the governor's Executive Council. The democratic responsibilities of islanders had been considerably increased. Once more the government publicity operation swung into action, but by mid-November the response had been so poor that the public were warned that in only two constituencies were there even enough registered voters to nominate a candidate. More registration forms were distributed and another warning about low numbers issued. 'It is very depressing', Field recorded. 'We can but battle on, in the hope that people will slowly become alive to the need to assume some sort of political responsibility.' The new bishop of St Helena and the current general secretary of the GWU also urged folk to register. But even with that boost, by 1 December 1967 the total amounted to only 598, less than a quarter of the adult population. Further efforts had by late January pushed the figure up to 653, but still substantially fewer than even the modest total in 1963. ${ }^{43}$ It was 'not good', though there were, at least, enough registered voters in each constituency to hold an election and enough to nominate candidates, if any came forward.

Late in December, Field knew of only six people willing to stand, but there were twelve seats to fill. The government publicity machine was cranked up again, urging more to volunteer. He even made it possible for someone to stand by bringing forward his date for retirement from government service, only to Field's dismay for this prospective candidate to say he was willing to be appointed to a council committee but not to stand for election. By early February 1968, it was still doubtful whether there would be enough candidates returned for him to be able to find chairs for the LegCo committees and thereby acquire the six members required to stock the Executive Council. In the event, there were no nominations for two of the twelve seats and only one candidate for each of the other ten, to be returned unopposed. ${ }^{44}$ There would be no contested Legislative Council elections in 1968. Democracy in St Helena still had shallow roots.

Field took some solace from the complexion of the ten candidates who had been returned. Numerically there were enough to serve as chairs of the LegCo committees and therefore enough to serve on the Executive Council and 'keep the Constitution working, which is better than I at one time feared'. Six had been members of the previous council, of whom he rated three as 'good men', and he thought that with experience two of the novices could also be good, and a third possibly useful 'if he doesn't prove a thorn in the flesh'. He kept his assessment of the remaining four even off the pages of his journal. 'It could have been a better council, but it might have been a great deal worse.' But to ensure that suitable persons would chair the council's committees and accordingly join his Executive Council, Field waited on the return after another uncontested by-election of an experienced councillor who regretted that he had not stood again at the general election. For Field, and for good government, it seemed worth the wait. He was also pleased to appoint as a chair one of the two women councillors elected, since this would also bring a woman on to the island's Executive Council, an appointment without precedent and perhaps, Field suspected with some pleasure, the first woman to serve on an Executive Council in any British colony. And, as another 'first', he was able to bequeath to his successor as governor 'an all-St Helenian ExCo', except for the two ex officio members. It was a landmark, and 'good from the point of view of getting Islanders to take responsibility for their own affairs'. 
The new Legislative Council first met on 26 March 1968. After the necessary formalities, Sir John addressed the members. It would be his last such occasion. He stressed the high importance of their committee work, and therefore urged them to arrange committee meetings outside normal working hours so that all members, especially those with contracted hours of employment, could attend. Moreover, because democratically elected representatives were answerable to the public, they should use the News Review and the government's radio broadcasting service (launched on Christmas Day 1967) to keep the public 'fully and accurately informed' of what they were doing. The new constitution was only one step, but a big one, towards 'the people of the Island assuming full responsibility for ordering their own affairs'. Their task was to develop it 'into a true "government of the people, by the people, for the people" of this island'. ${ }^{45}$ After that ringing peroration, Field that evening hosted a dinner party for councillors, which 'went very well'. As did the first and for Field his only meeting of the newly constituted Executive Council. He could not resist again mentioning in his journal that this was the first made up entirely of St Helenians, including a woman, with only a couple of ex officio chaps in attendance. The business in hand progressed smoothly and 'it may well turn into a good and useful Council'.

\section{V}

By the time Sir John Field left St Helena in May 1968 he had largely completed the constitutional agenda he had set himself on arrival. He had given Saints their first taste of democratic government; the half-elected Advisory Council he had inaugurated in 1963 had become an almost wholly elected Legislative Council; elected members sat on committees responsible for government business; and islanders as chairs of those committees served alongside just two senior expat officials in an Executive Council presided over by the governor. Field was gratified to learn when on leave in London in 1967 that 'my new constitution for St Helena was exciting interest as a model for other small colonies'. He also told Commonwealth Office staff in June 1968, when reviewing his time as governor, that he was 'very satisfied' with the way the new constitution and the LegCo committees were working and that Saints were beginning to take an interest in their activities. ${ }^{46}$

And yet when he summed up his achievements privately in his journal he thought he had not 'done so very much', except improve wages, start a children's home and provide better housing. Interestingly, these are examples of top-down 'good government' rather than of constitution-making and 'self-government' to which he had dedicated much thought and energy, and which one might regard as his more far-reaching legacy. Today’s Legislative Council, its committees, and the Executive Council are derived from Field's innovations, though since 1988 the chairs of council committees have not been chosen by the governor but elected by LegCo members, as Field had indeed anticipated. ${ }^{47}$ Possibly in his mind was his disappointment at how hard it had been to introduce not so much democratic structures as democratic participation. He had after all been brought in as governor when the demand for radical democratic reform seemed to threaten a breakdown in government, and yet he was soon recording the political apathy of most islanders, as had his predecessors and indeed as did his successors in office. In LegCo general elections in 1972 two seats were uncontested (and five filled by expatriates) and four in 1976; nine unopposed candidates were returned in 1980 and no nominations for the other three seats; and in 1984 four candidates were unopposed. $^{48}$

What had not been sustained was the political agitation which had preceded his appointment as governor. The GWU had certainly shaken up St Helena, but officials in Jamestown and in 
London had always suspected that huge membership numbers, public demonstrations and the apparently popular demand for constitutional change owed much to Fred Ward's leadership. In fact, when they met, Field was soon persuaded that Ward was not a 'South Atlantic Fidel Castro', as some expat settlers implied, but a local man looking for 'a legitimate outlet for his undoubted ability'. Ward too was frustrated in his role of agitator, and in need of gainful employment. In October 1962 he applied for the vacant government post of Social Welfare Officer, in which role he believed (correctly, as it turned out) he could do good by addressing some of St Helena's social problems. Field's decision to appoint him was not a cunning plan to muzzle a troublemaker, for he had hoped Ward 'would stand for election and come on the Executive Council where he would be a useful and lively member'; but he was 'incomparably the strongest candidate' for the job. ${ }^{49}$ Unfortunately, Ward attempted to retain some authority over the GWU, and the consequences were bitter public disputes with the new leadership and a fall in membership. Remarkably, a delegation from the GWU in July 1965, which met two MPs on an official visit, had several criticisms of government policies and practices but raised no complaints about the constitution, this when there was still only a halfelected Advisory Council. It was left to one of the visitors to urge St Helenians to 'take more responsibility in the conduct of Government'. ${ }^{50}$ The union partly recovered its support and canvassed at elections in favour of GWU members, and after the 1972 general election those returned labelled themselves the St Helena Progressive Party. But though they were active as councillors, and the union lobbied hard on issues concerning the economy and social welfare, its mass appeal diminished, and the union itself, like the party, evaporated. ${ }^{51}$ What Field had feared occurred. Without Ward, popular engagement in democratic politics became harder to sustain.

Colonial regulations operating in St Helena, as elsewhere, may have compounded the problem because they barred people holding 'offices of profit under the Crown' from serving as elected members. Those employed by the government, even in humble capacities, had to resign their posts to serve as councillors, or resign as councillors if taking up a government job. Field regretted a restriction which 'cuts out some of the best potential material'. It was particularly inhibiting because the proportion of the employed population working in the private sector fell when, for instance, the decline in the flax and fibre industry and related occupations accelerated, at the same time that public sector employment increased as government services grew. ${ }^{52}$ Moreover, serving as a councillor was voluntary work. It took up time, more so when Field's creation of LegCo committees obliged councillors to get more involved in administration and meet frequently. There were financial costs too, especially for the chairs of committees because they had further obligations as members of the governor's Executive Council. This was something Field managed only marginally to address: councillors received a modest allowance to cover expenses and loss of earnings while on government business, but they were not paid, though Field thought they should be. ${ }^{53}$ Moreover, a population of fewer than 2500 adults was no more likely to have spawned politically determined islanders with time to spare from the gruelling business of earning a living than an equivalent sized community in Britain, where local elections are often characterised by uncontested seats and low turn-outs.

However, politics in St Helena probably also suffered from the loss of population overseas. (Hence, until recent decades, pretty much the stability of the island's post-war resident population in spite of natural increase). Until apartheid rules kicked in and excluded them, many islanders had left to work or even to settle in South Africa. Thereafter, increasing numbers of Saints worked on Ascension, numbering 403 in 1966, equivalent to a quarter of the employed labour force on St Helena. Many more migrated to the UK, some 1500 in 'recent years' it was reckoned in 1965, until the 1981 British Nationality Act made it much 
more difficult for those defined as citizens of 'the dependent territories', like St Helenians, to secure rights of residence. ${ }^{54}$ Moreover, while those otherwise qualified and registered in St Helena but temporarily off island could vote, by proxy, there is no indication that they did. ${ }^{55}$ It is also probable that many of those who left the island, temporarily or permanently, were among the more enterprising and also those who had derived most from an educational system generally regarded as poor by UK standards. Certainly, islanders had always had to go overseas for further education and technical training. Not surprisingly, many so geared up did not return, and some whose funding required them to return (particularly teachers) did not permanently stay - because pay and prospects seemed brighter off-island. ${ }^{56}$ It would be an exaggeration to state that political involvement and political skills depend on high levels of formal education, but considering the role played by university graduates and skilled workers in, for instance, anti-colonial movements in Africa, the West Indies and elsewhere, it is probable that St Helena's politics were inhibited by their absence.

Cultural features were also less provocative of political agitation than elsewhere in the colonial empire. St Helena had been innocent of sustained human settlement until the East India Company arrived in 1659, and so there was no indigenous culture or 'native' form of self-government, particularly at local level, with which colonial rulers could or must engage and which elsewhere in empire provided a voice for the governed - as indeed Field had encountered earlier in his career in West Africa and as he would meet again in the South Pacific. ${ }^{57}$ What had developed in St Helena was a remarkably interbred population of mixed ethnic including European origins, almost all locally born. While some white settlers and expat government officials were occasionally accused of racial prejudice, interestingly by Fred Ward who was sensitive to racism having worked in South Africa, ${ }^{58}$ there was nothing as provocative as an overt colour bar. In 1962, seven of the administration's twenty-one senior officials and all other government posts were held by islanders, ${ }^{59}$ and subsequently Field was to recruit still more (including his ADC in 1966). In fact, a monolingual English and intensely British culture emerged, devoted to British sports and youth movements, keen on pubs and clubs, enthusiastically loyal to the crown, and overwhelmingly Church of England but tolerant of other faiths. ${ }^{60}$ Noticeably neither church nor chapel became politicised institutions, as happened in other societies, and not just in British colonies. ${ }^{61}$ Hughes in his report suggested that political passivity was due to the slave roots (in the East India Company period) of many in the population. But paradoxically it may have been the very Britishness of St Helena which induced a passive toleration of British colonial rule.

That passivity may even have been a result of Governor Field's efforts to generate its opposite. His constitutional reforms probably reduced such political discontent as Ward had once managed to mobilise: inaction would surely have provoked a resentful reaction. Moreover, Field had also endeavoured to erode the space, endemic in colonies, between himself and senior expat officials on the one hand and local people on the other. 'There is without doubt a gulf between the Castle and the people', and it was 'most important that it should be bridged'. Not least for political reasons, he had made social contacts beyond the few members of the well-to-do elite. Hence, for example, his attendance at GWU sports days and dances, his engagement as Chief Scout with youth movements, his reading of the lesson at Sunday services in the island's churches, the lavish hospitality (much at his own expense) which brought islanders to Plantation House (the governor's residence) in unprecedented numbers, and the drinks parties he arranged in outlying communities so he could 'mix among more St Helenians'.

Moreover, while visitors were always disturbed by standards of living on St Helena which fell some way below UK expectations, this was not such a hierarchical society of wealth and 
status that relative deprivation internally was sufficient to provoke political protest. Even that limited sense of 'missing out' on something better, of which returned migrants might have been aware, was otherwise contained by the island's extraordinary physical isolation and until recently limited telecommunications contacts with the outside world. Not surprisingly, then, some of those who did take up political causes were expats, but only 85 were so classified in the 1987 census, and nearly all worked for government. In any case, some benefits of colonial rule were being felt, even while the economy struggled. Field, for example, offset the decline in the flax and fibre industry by relief works, more government employment (and at rates of pay which set higher standards in the private sector), price subsidies and improvements in the island's housing, health, education and other services. ${ }^{62}$

All this was to the good, but these and later developments were invariably top-down reforms, often designed by external consultants, governors and ex pat officers with the input and approval of officials and ministers in London. Islanders, and even elected councillors, were induced to receive passively top-down policies in whose formulation they had scarcely been involved. ${ }^{63}$ Moreover, little of this expenditure was derived from locally-raised resources. Had St Helena itself been able to generate substantial revenues for government to tax, by attracting inward investment and boosting external trade, there would more likely have been intense political debate about how much should be raised and by what means and from whom, to fund which investments or services and for whom. ${ }^{64}$ As it was, governors alone had to negotiate with the UK government to secure annual grants-in-aid upon which, in increasingly large amounts, St Helena has been dependent in almost every year since 1907, just to meet recurrent budgetary costs. Similarly, local debates over development fund expenditure were constrained, as for other dependent territories, by the island's allocation which was largely settled, also in increasing amounts, by the Colonial Office and its successors in negotiation with the Treasury. ${ }^{65}$ In sum, financial dependence discouraged local initiatives, inhibited local argument about policies and priorities, and generated what might best be described as a grumbling but passive dependency culture. ${ }^{66}$ As Field himself acknowledged, the business of government, with which Saints were urged to engage, was therefore largely about day-to-day administration and not the high profile policy matters which raised political temperatures in other places. If financial independence stimulates selfgovernment, more than vice versa, at least initially, then it is less of a surprise that a culture of political involvement was hard to generate and sustain in St Helena. An airport, constructed at huge expense to the UK government, is scheduled to open in 2016, and some public utilities are being privatised. ${ }^{67}$ It remains to be seen whether this will pull in private investors, boost the island economically through tourism, make the government financially self-sufficient, suggest independence at last as an option, or at least further engage the public in the democratic politics that Sir John Field had been so keen to encourage.

\section{References}

Aldrich, Robert and John Connell. The Last Colonies. Cambridge: Cambridge University Press, 1998.

Ashton, S.R. and Wm Roger Louis (eds). East of Suez and the Commonwealth 1964-1971. London: Stationery Office, 2004.

Cannan, Edward. Churches of the South Atlantic Islands, 1502-1991. Oswestry: Anthony Nelson, 1992.

Cawkell, Mary. The History of the Falkland Islands. Oswestry: Anthony Nelson, 2001.

Cohen, Robin. Labour and Politics in Nigeria 1945-71. London: Heinemann, 1974. 
Cohen, Robin. 'St Helena: Welfare Colonialism in Practice', in Robin Cohen (ed.), African Islands and Enclaves. Beverly Hills: Sage, 1983.

Cohen, Robin. 'Education for Dependence: Aspirations, Expectations and Identity on the Island of St Helena', in Paul Cook (ed.), Small Island Economies. Manchester: University of Manchester, 1983.

Constantine, Stephen. Community and Identity: The Making of Modern Gibraltar since 1704. Manchester: Manchester University Press, 2009.

Constantine, Stephen. 'Cledwyn Hughes, M.P. for Anglesey - and St Helena'. Welsh History Review, 27, no 2 (2015), 552-73.

Cross, Tony. St Helena, including Ascension Island and Tristan da Cunha. Newton Abbot: David and Charles, 1980.

Darwin, John. The End of the British Empire. Oxford: Blackwell, 1991.

Drower, George. Britain's Dependent Territories: a Fistful of Islands. Aldershot: Dartmouth, 1992.

Evans, Dorothy. Schooling in the South Atlantic Islands 1661-1992. Oswestry: Anthony Nelson, 1994.

Gillett, Simon. 'Developing St Helena.' Public Administration and Development, 3 (1983): 151-60.

Goldsworthy, David (ed.). The Conservative Government and the End of Empire 1951-1957. London: HMSO, 1994.

Gosse, Philip. St Helena 1502-1938. London: Cassell, 1938 (reprinted Oswestry: Anthony Nelson, 1990).

Holland, R.F. European Decolonization 1918-1981. Basingstoke: Macmillan, 1985.

Hughes, Cledwyn. Report of an Enquiry into Conditions on the Island of St Helena. Llangefni: Jones, [1958].

Hyam, Ronald (ed.). The Labour Government and the End of Empire 1945-1951. London: HMSO, 1992.

Hyam, Ronald and Wm Roger Louis (eds). The Conservative Government and the End of Empire 1957-1964. London: Stationery Office, 2000.

Hyam, Ronald. Britain's Declining Empire: The Road to Decolonisation 1918-1968. Cambridge: Cambridge University Press, 2006.

Lynn, Martin (ed.). Nigeria, 1943-1960. London: Stationery Office, 2001.

Macdonald, Barrie. Cinderellas of the Empire: Towards a History of Kiribati and Tuvalu. Suva: University of the South Pacific, 2001.

McIntyre, W. David. 'The Admission of Small States to the Commonwealth.' The Journal of Imperial and Commonwealth History, 24, no.2 (1996): 244-77.

McIntyre, W. David. British Decolonization, 1946-1997. Basingstoke: Macmillan, 1998.

McIntyre, W. David. Winding Up the British Empire in the Pacific Islands. Oxford: Oxford University Press, 2014.

Meynaud. Jean and Anisee Salah Bey. Trade Unionism in Africa. London: Methuen, 1967. 
Moore, Robert. 'The Debris of Empire: the 1981 Nationality Act and the Oceanic Dependent Territories.' Immigrants and Minorities, 19, no.1 (2010): 1-24.

Morgan, D.J. The Official History of Colonial Development, 5 vols. London: Macmillan, 1980.

Roberts, B.C. Labour in the Tropical Territories of the Commonwealth. London: Bell, 1964.

Royle, Stephen A. A Geography of Islands: Small Island Insularity. London: Routledge, 2001.

Schulenburg, Alexander Hugo. "Transient Observations. The Textualizing of St Helena through Five Hundred Years of Colonial Discourse.” PhD diss., University of St Andrews, 1999.

Smallman, David L. Quincentenary: A Story of St Helena, 1502-2002. Penzance: Patten Press, 2003.

Smith, John. An Island in the Autumn. Kinloss, Morayshire: Librario, 2011.

${ }^{1}$ The governor's responsibilities also included supervision of the separate administrations in Ascension Island and Tristan da Cunha.

${ }^{2}$ Little has been written about, especially, the modern history of St Helena, but see Gosse, St Helena, Cross, St Helena and Smallman, Quincentenary. Unreferenced quotations from primary sources are from Field's journal, Oxford, Bodleian Library, Field Papers, Mss.Brit.Emp.s.566. Referenced sources include Lady Margaret Field's unpublished Memoirs and Diaries also in Field Papers (henceforth, MF), records in St Helena Government Archives (SHGA), Cabinet, Colonial Office, Dominions Office, Foreign Office and Treasury papers in the National Archives (CAB, CO, DO, FCO, T); TUC Archive, Modern Records Centre, Warwick University (MRC); TUC Library, London Metropolitan University (LMU); Lord Cledwyn of Penrhos Papers, National Library of Wales (NLW).

${ }^{3}$ CO1024/326, 'St Helena Order in Council 1956', 'St Helena Royal Instructions 1956'.

${ }^{4}$ CO1058/32, ‘St Helena (Constitution) Order 1966’, St Helena Government Gazette, 6 Jan 1967.

${ }^{5}$ Among the considerable scholarly literature see, for succinct assessments, Darwin, End of the British Empire, McIntyre, British Decolonization, Holland, European Decolonization; plus Hyam, Britain's Declining Empire, based substantially on UK government sources.

${ }^{6}$ McIntyre, 'The Admission of Small States to the Commonwealth'.

${ }^{7}$ Morgan, Colonial Development, vol.5, and McIntyre, Pacific Islands. For a selection from the immense documentation see the British Documents on the End of Empire series, covering the years 1945-71, edited by Hyam; Goldsworthy; Hyam and Louis; Ashton and Louis.

Particularly important documents in National Archives include CAB134/56, CA1(49), 19 Jan 1949; CO967/146, March 1951; CAB129/77/133, CP(55)133, 27 Sept 1955; CAB134/1556, CPC(57)30, 6 Sept 1957; CO1032/234, Oct 1962; CO1032/400, 10 April and 20 June 1963; CO1032/404, 26 May 1965; CAB148/22, OPD(65)127, 14 Sept 1965.

${ }^{8}$ See, for example, references in CAB129/33/2, CP(49)62, 10 March 1949; CAB129/77/33, CP(55)133, 27 Sept 1955; DO35/7873, minute by Chadwick, 11 Dec 1958; CO1032/400, 
memo 27 Sept 1963; CO1032/403, memo 3 Feb 1965. For case studies of constitutional change in other 'small colonies' and of the remaining legacies of empire see Aldrich and Connell, Last Colonies; Drower, Britain’s Dependent Territories; McIntyre, Pacific Islands; Constantine, Gibraltar.

${ }^{9}$ The Overseas Territories, Cm.8374, 2012.

${ }^{10}$ SHGA, Governor Davis to CO, 5 May, 12 Dec and Confidential Dispatch, 5 May 1933; Governor Joy to CO, 20 Jan 1949, 16 Sept 1953; Governor Harford to CO, 23 Jan 1954; CO537/4389, Joy to Committee of Enquiry into Constitutional Development in Smaller Colonial Territories, 23 Nov 1949.

${ }^{11}$ SHGA, Joy to CO, 11 Oct 1949; CO537/4391, paper by Joy, Nov 1949; CO1024/67, Joy to Sidebotham, 8 Aug 1952.

${ }^{12}$ CO1024/188 and /189, correspondence and minutes, 12 Feb 1954-28 May 1956; SHGA, Harford's speeches to joint meeting of Executive and Advisory Councils, 22 July 1955, 27 Aug 1956, 29 Nov 1957.

${ }^{13}$ Constantine, 'Cledwyn Hughes'; NLW, Callaghan to Hughes, 27 March 1958, enclosing Wells to Labour Party, 27 Jan 1958; Cledwyn Hughes, Report of an Enquiry into Conditions on the Island of St Helena (Llangefni: Jones, [1958]); CO1024/276, for governor's indignant response; Hansard, House of Commons, Hughes, parliamentary questions 16 Feb 1960-4 Dec 1962.

${ }^{14}$ Schulenburg, 'Transient Observations', 275-7; MRC, Mss292/966.9/1, Nicholson, 19 March 1959, Ward to Secretary of State, 26 Aug 1960; SHGA, The St Helena Wirebird [henceforth Wirebird], Ward letters, 1954-8.

${ }^{15}$ SHGA, St Helena News Review [henceforth SHNR], 26 July-16 Aug, 27 Sept, 18 Oct, 20 Dec 1958; CO1024/276, Alford to CO, 16 Aug 1958; MRC, Mss 292/ 966.9/1, Ward to TUC, 5 May and to Hughes 13 July 1959; CO1023/275, 22 June-6 Nov 1959; CO1024/275, report by government secretary, with Alford to CO, 23 Sept 1959; GWU photographs in Schulenburg, 'Transient Observations', 276, and St Helena Museum.

${ }^{16}$ CO1024/277, Ward to CO, 17 April 1959; CO1024/275, Emanuel to Alford, 1 Dec 1959; Wirebird, April 1959; Voice of the Union, 1961-2, copies in SHGA, MRC, LMU.

${ }^{17}$ For connections between colonial trade unionism and political activism see near contemporary accounts in Meynaud and Bey, Trade Unionism, 49-80; Roberts, Labour in the Tropical Territories, 85-121, 123, including membership numbers in 1958 and 1960; and see also Cohen, Labour and Politics, and Constantine, Gibraltar, 321-31, 346-9, 381-4.

${ }^{18}$ CO1024/233, Alford to CO, 25 April 1958, minutes and subsequent correspondence; T220/552, CO-Treasury correspondence concerning low wages and poor nutrition, 7 Oct 1958-5 Aug 1959.

${ }^{19}$ CO1024/233, Emanuel to CO, 28 March-8 April 1959; CO1024/260, 'Report on a Visit to St Helena, March-April 1959'.

${ }^{20}$ CO1024/252, 7 April 1959-4 Jan 1960, /326, 22 Jan 1960-25 Oct 1962, esp Macleod to Fenner Brockway, 15 Feb, and Fraser to Hughes, 27 April 1961; Hansard, House of 
Commons, Macleod, 13 June 1961; CO1024/244, Alford's Address to the Advisory Council, 7 Oct 1959; MRC, Mss 292/966.9/1, and Mss 292B/966.7/2, correspondence, including with Ward, Hughes and CO, May 1959-March 1962, especially Ward to Secretary of State, 26 Aug 1960, 'Note on Telephone Conversation' with Pettitt in CO, 8 Sept, and Ward to Woodcock, 9 Oct 1961; SHNR, 29 Aug 1959 and Wirebird, editorial, Jan 1961.

${ }^{21}$ National Archives, OD8/110, minute by Emanuel, 11 Aug 1961.

${ }^{22}$ Details of Field's career are derived from Colonial Office Lists; Who Was Who 1981-90; The Times, 27 Feb 1962 and 18 March 1985; MF, Memoirs and Diaries. For the politics of change in Nigeria and the Cameroons see introduction and documents in Lynn, Nigeria.

${ }^{23}$ MRC, Mss 292B/966.7/2, report of Field meeting at TUC, 26 March 1962; CO1024/326, CO meeting with Field and Alford, 30 March 1962.

${ }^{24}$ MRC and LMU, Voice of the Union, 10 Feb 1962; CO1024/326, Acting Governor to CO, 17 March 1962.

${ }^{25}$ CO1024/326, Alford to Eastwood, 21 March 1962.

${ }^{26}$ CO1024/326, minute by Browning, 15 Nov, Emanuel to Alford, 17 Nov, and Fraser to Hughes, 17 Nov 1960; Hughes to CO, 2 May 1961 and 18 April 1962; CO1024/328, background note on Hughes Parliamentary Question, 12 April 1962; NLW, Ward to Hughes, 6 June 1961; MRC, Mss 292B/966.7/2, Woodcock to Ward, 11 Sept 1961.

${ }^{27}$ CO 1024/326, Emanuel to Alford, 10 Jan, and Alford to CO, 17 Oct 1961; CO1024/355, background note for reply to Hughes Parliamentary question, 13 June 1961; SHGA, Alford to CO, 23 June 1961, and Alford to Executive and Advisory Councils, 22 Nov 1961.

${ }^{28}$ CO1024/326, Acting Governor to CO, 17 March, CO to Acting Governor, 27 March, minute by Pettitt, 30 March, and Hughes to Fraser, 18 April 1962; MRC, Mss 292B/966.7/2, Ward to Woodcock, 30 April 1962; MRC and LMU, Voice of the Union, 10 Feb 1962, and, in SHGA, 7 April 1962; SHNR, 14 April 1962.

${ }^{29}$ CO1024/473, Field to Poynton, 17 Dec 1962.

${ }^{30}$ CO1024/497, Field to Eastwood, 30 April 1963; CO1024/561, Field to CO, 23 Sept 1963.

31 SHNR, 3 Aug 1963; CO1024/497, Field to Eastwood, 26 Aug 1963.

32 SHNR, 7 Sept 1963; Wirebird, Aug 1963.

33 SHNR, 14 Sept 1963; Wirebird, Sept 1963.

${ }^{34}$ Wirebird, Oct 1963.

${ }^{35}$ SHNR, 4, 11 Sept, 20 Nov 1965.

${ }^{36}$ Wirebird, Oct 1963.

${ }^{37}$ Calculated from Field's journals.

${ }^{38}$ Wirebird, Oct 1963; SHGA, 'Report of the Advisory Committee on the Improvement of the Housing Population, 17 Jan 1964’; CO1024/497, Field to Eastwood, 31 Jan 1964. 
${ }^{39}$ CO1024/472, Field to Eastwood, 30 Sept, 4 Oct 1965, minutes, Eastwood to Field, 1 Dec 1965.

${ }^{40}$ CO1024/598, Field to Eastwood, 9 March 1966.

${ }^{41}$ CO1024/598, Eastwood to Field, 23 May 1966; CO1058/32, Sept-Nov 1966.

${ }^{42}$ FCO42/273, Field to Staveley, 21 Nov 1967.

${ }^{43}$ SHNR, 28 Oct 1967-13 Jan 1968.

${ }^{44}$ SHNR, 17 Feb 1968.

45 SHNR, 30 March 1968.

${ }^{46}$ FCO42/275, 'Record of Talks with Sir John Field', 26-27 June 1968. The Colonial Office and the Commonwealth Relations Office had been merged to form the Commonwealth Office on 1 August 1966, prior to its own absorption into the Foreign and Commonwealth Office on 17 Oct 1968.

${ }^{47}$ Smallman, Quincentenary, for constitutional changes to 2002.

${ }^{48}$ SHNR reports; FCO44/945, Haselhurst report, 1972; FCO44/2200, Guy to FCO, 5 Dec 1980.

${ }^{49}$ CO1024/326, Field to Kisch, 31 Aug 1962; CO1024/336, Field to Eastwood, 28 Sept 1962; Bodleian Library, Rhodes House, Weston Papers, Mss Atlan.s.9, Weston to Field, 1962; CO1024/572, Ward to Hughes, 29 April 1965.

${ }^{50}$ SHGA and LMU, Voice of the Union, 30 Nov 1962, 21 Nov 1964, and Ward 'Circular', 3 Oct 1964; MRC, Mss292B/966.7/2, Ward to TUC, 20 Oct 1964; CO1024/530, report on GWU meeting with Armstrong and Harrison, 23 July, and their reports, Sept and Oct 1965.

${ }^{51}$ FCO44/933, 'Political parties in St Helena', 1973; FCO44/1546, Guy to CRO, 10 Feb 1977; interview with Mr Eric Benjamin, former GWU general secretary, St Helena, 1 Dec 2012.

${ }^{52}$ CO1024/497 Field to Eastwood, 30 April 1963. Still an unresolved issue in 1987, when around 75 per cent of those in employment were thereby excluded: London University, Senate House Library, Wallace, 'Review of the Constitution of St Helena'.

${ }^{53}$ CO1058/32, Field to Commonwealth Office, 22 Nov 1966; FCO42/275, 'Record of Talks with Sir John Field’, 26-27 June 1968. Councillors were not paid until 1997.

${ }^{54}$ Census of the Population of St Helena and Ascension Island 1966; CO1024/530, Armstrong report, Sept 1965; reports of the Bishop of St Helena's Commission on Citizenship, St Helena: The Lost County of England, 1994, and St Helena: a British Island, 1997; Moore, 'Debris of Empire'.

${ }^{55}$ Wallace, 'Review'.

${ }^{56}$ Among many critical comments on standards of education, emigration of teaching staff, staff shortages, effects on aspirations and implications for political engagement see St Helena Annual Reports, almost every year 1948-57; CO1024/188, Harford, 20 July 1954, minute, 16 
Sept 1954; reports referenced above by Hughes, 1958, Emanuel 1959, Harrison and Armstrong, 1965; Cohen, 'Education for Dependence', 1983; John Marek M.P. and Jonathan Sayeed M.P., St Helena - The Isolated Island, 1984 (copy in St Helena Public Library). See also Evans, Schooling, 120-1, 137-40, and for recent scholarships awarded for university study abroad 186, 206.

${ }^{57}$ On politics in the Gilbert and Ellice Islands see Field's journals, the memoirs of his successor Smith, An Island, Macdonald, Cinderellas, McIntyre, Pacific Islands.

${ }^{58}$ Wirebird, Ward letter, June 1958; SHGA, LMU, Voice of the Union, [June 1961?]; CO1024/275, report by Lewis.

${ }^{59}$ CO1024/473, Field to Poynton, 17 Dec 1962.

${ }^{60}$ See, amongst much else, Hughes, Report, 1958; CO1024/473, Field to Poynton, 17 Dec 1962; MRC, Mss292B/966.7/2, Ward to Woodcock, 29 June 1963; CO1024/530, report by Harrison, 7 Sept 1965; FCO44/2198, Guy to FCO, 5 Aug 1980.

${ }^{61}$ Nothing to the contrary is suggested in Cannan, Churches.

62 Summarised in St Helena Annual Reports.

${ }^{63}$ Forcefully criticised by Cohen, 'Welfare Colonialism'.

${ }^{64}$ For lively examples see Constantine, Gibraltar, chaps 9-10.

${ }^{65}$ St Helena Annual Reports; http://www.sainthelena.gov.sh/wpcontent/uploads/2013/07/2012.13-Statistical-Yearbook-completed-PDF.pdf, Table 1.2, 'UK Aid to St Helena'; accessed 19 March 2015; Royle, Geography of Islands, 217-8; Morgan, Colonial Development, especially vol.3, 271-317.

${ }^{66}$ Argued in 1965 by visiting MPs Armstrong and Harrison, C01024/530, in 1983 by Gillett, 'Developing St Helena' (he had been government treasurer and development secretary, 197881), and in 2012 by Benjamin, interview. A diffidence for similar reasons was said to inhibit elected councillors even in the post-1982 Falkland Islands: Cawkell, Falkland Islands, 150.

${ }^{67}$ http://www.sainthelena.gov.sh/vision/sustainable-development-plan-sdp-2014-17/, accessed 19 March 2015. 